\title{
PENGARUH KUALITAS PELAYANAN PERPUSTAKAAN TERHADAP KEPUASAN MAHASISWA DI POLITEKNIK NEGERI MEDIA KREATIF
}

\author{
Dadang Syaputra \\ Politeknik Negeri Media Kreatif, Jakarta Selatan, DKI Jakarta \\ Email : ${ }^{1}$ syaputradadang36@gmail.com
}

\begin{abstract}
ABSTRAK
Penelitian ini bertujuan untuk mengetahui seberapa besar pengaruh kualitas pelayanan terhadap kepuasan mahasiswa di Politeknik Negeri Media Kreatif Jakarta.. Populasi yang digunakan dalam penelitian ini adalah seluruh mahasiswa Politeknik negeri media kreatif yang terdiri dari 3 jurusan. Sampel dalam penelitian ini adalah 211 responden dan teknik yang digunakan adalah teknik sampel acak (random sampling). Dari hasil analisis, indikator dalam penelitian ini semua dinyatakan valid dan variabel kualitas layanan dinyatakan berpngaruh positif dan signifikan terhadap kepuasan mahasiswa. Saran penulis adalah untuk perpustakaan politeknik negei media kreatif agar bisa selelau mempertahankan kualitas layanan yang diberikan dan jika bisa selalu ditingkatkan sehingga akan selalu berdampak positif terhadap kepuasan mahasiswa yang menjadi tujuan utama pelayanan yang dilakukan.
\end{abstract}

Kata Kunci : Kualitas Layanan dan kepuasan Mahasiswa

\section{Latar Belakang}

Pada era teknologi dan informasi yang moderen seperti ini, kebutuhan masyarakat terhadap informasi dan media edukasi merupakan hal penting dan menjadi tantangan tersendiri bagi penyedia jasa informasi dan edukasi yang ada di Indonesia. Lembaga pendidikan yang bergerak di bidang edukasi dan informasi juga tidak luput dari perkembangan teknologi informasi yang cepat dan tuntutan untuk meningkatkan pelayanan di bidang pendidikan. Hal tersebut membuat lembaga pendidikan mulai dari tingkat dasar sampai ketingkat perguruan tinggipun meningkatkan kinerjanya dalam hal pelayanan pendidikan dan informasi yang dibutuhkan masyarakat khususnya insan akademik. Hal tersebut juga dapat memotivasi lembaga pendidikan untuk melakukan transformasi struktur dan strategi pengembangan sarana pendidikan yang unggul dan terpercaya.

Pelayanan merupakan suatu bentuk kegiatan sosial untuk membantu orang lain dan mempunyai tujuan membangun kerja sama antar pihak dalam jangka panjang dengan prinsip saling menguntungkan antar pihak terkait. Pelayanan yang bagus adalah pelayanan yang dapat memahami keinginan dan kebutuhan konsumen serta berusaha untuk memberikan nilai lebih kepada pelanggan. Lembaga pendidikan seperti perguruan tinggi harus berupaya ikut serta meningkatkan kualitas pelayanan pendidikan mereka, karena kualitas pelayanan pendidikan merupakan usaha yang dapat meningkatkan citra / nama baik dimata pelanggan khususnya mahasiswa.

Menurut Zeithaml, et.al (2005: 20), Kualitas layanan dapat didefinisikan sebagai seberapa jauh perbedaan antara kenyataan dengan harapan para pelanggan atas layanan yang mereka peroleh, hal ini berarti bahwa citra kualitas yang baik tidak berdasarkan persepsi penyedia jasa, akan tetapi berdasarkan persepsi pelanggan.

Politeknik Negeri Media Kreatif adalah politeknik negeri yang ada di wilayah Srengseng Sawah Jakarta Selatan, Politeknik Negeri Media Kreatif diharapkan bisa menciptakan SDM yang berkualitas yang sudah siap terjun kedunia usaha maupun dunia kerja dengan modal ilmu yang maksimal dibidangnya. Untuk itu Politeknik Negeri Media Kreatif yang merupakan memberikan dorongan dan fasilitas yang dibutuhkan agar tidak 
terjadi permasalahan dalam mencapai tujuan yang diharapkan. Adapun yang menjadi perhatian adalah fasilitas gedung yang sangat baik, alat dan media belajar serta praktek yang cukup, dan yang paling penting disediakan tenaga-tenaga yang berkualitas dan sesuai dengan bidang yang diperlukan baik tenaga pengajar selaku dosen maupun tenaga teknis yaitu pegawai. Selain itu, perpustakaan Politeknik Negeri Media Kreatif merupakan suatu unit kerja yang memberikan pelayanan pendukung pendidikan misalnya di bidang perpustakaan. Kebutuhan konsumen khususnya mahasiswa terhadap ilmu pengetahuan dan media edukasi lainnya merupakan hal yang sulit untuk dipisahkan karena perpustakaan merupakan salah satu sarana penunjang akademik yang dibutuhkan konsumen seperti mahasiswa.

Memberikan pelayanan yang dapat memberikan kepuasan kepada mahasiswa bukanlah merupakan hal mudah, sering juga ditemukan masalah pada pelaksanaan yang membuat mahasiswa tidak nyaman. Oleh karena itu, diperlukan perencanaan yang matang dan fasilitas yang memadai agar tercipta kepuasan mahasiswa. Menurut Zeithaml (2005: 78), Kepuasan pelanggan adalah perbandingan antara persepsi pelanggan terhadap jasa yang diterima dan harapannya sebelum menggunakan jasa tersebut. Ada hubungan yang erat antara kualitas pelayanan dengan kepuasan mahasiswa. Kualitas pelayanan yang baik dapat membuat mahasiswa mau berkunjung ke perpustakaan Politeknik Negeri Media Kreatif dan dari hubungan tersebut pengelola perpustakaan dapat mengidentifikasi keinginan dan kebutuhan mahasiswa, sehingga Politeknik Negeri Media Kreatif dapat meningkatkan hal-hal yang dapat membuat mahasiswa senang atau puas terhadap pelayanan yang diberikan.

Perpustakaan Politeknik Negeri Media Kreatif merupakan salah satu unit jasa pelayanan mahasiswa yang berkomitmen untuk menyediakan sarana dan fasilitas media edukasi untuk menunjang kegiatan akademik dari tiap jurusan yang ada di Politeknik Negeri Media Kreatif yaitu Jurusan Desain, Jurusan Teknik Grafika, dan Jurusan penerbitan. Oleh sebab itu Perpustakaan Politeknik Negeri Media Kreatif sangat berperan penting dalam media penunjang untuk referensi mahasiswa belajar baik teori maupun praktikum.

Namun pada kenyataannya, pelayanan perpustakaan yang diberikan pengelola belum memuaskan mahasiswa dan ini menjadi tugas bagi pengelola perpustakaan untuk mengidentifikasikan kebutuhan mahasiswa dan berupaya meningkatkan pelayanan dengan saran yang ada. Setiap mahasiswa mempunyai penilaian sendiri terhadap pelayanan yang diterima, sehingga pengelola perpustakaan perlu membuat prioritas dalam program peningkatan kualitas layanan karena sulit bagi pengelola bila harus memenuhi semua kebutuhan mahasiswa karena berbagai keterbatasan. Persepsi pelanggan dapat dipengaruhi oleh kinerja dan kualitas jasa yang diterimanya, oleh karena itu pengelola perpustakaan harus berupaya meningkatkan kinerjanya agar mahasiswa merasa puas dan mau berkunjung kembali, dilihat dari daftar kunjungan yang dilakukan mahasiswa selama periode 2016-2018 sebagai berikut :

\section{Tabel 1}

Pengunjung perpustakaan Politeknik Negeri M edia Kreatif ,2016-2018

\begin{tabular}{|c|c|c|c|}
\hline No & Tahun & Total Pengunjung & Persentase \\
\hline 1 & 2016 & 1845 & - \\
\hline 2 & 2017 & 2237 & 21,25 \\
\hline 3 & 2018 & 2030 & 9,25 \\
\hline
\end{tabular}

Dilihat dari tabel 1 di atas bahwa pengunjung perpustakaan Politeknik Negeri Media Kreatif fluktuatif mengalami peningkatan dan penurunan, di tahun 2016 jumlah pengunjung 1845 dan meningkat di tahun 2017 sebanyak 2237 pengunjung kemudian mengalami penurunan lagi menjadi 2030 pengunjung. Kenaikan dan penurunan tersebut tidak terlepas disebabkan oleh kualitas layanan perpustakaan Politeknik Negeri Media Kreatif dalam menangani pengunjung dan kebutuhannya. Permasalahan yang terjadi yang berkaitan dengan 
kualitas layanan diantaranya kurang lengkap fasilitas buku di perpustakaan, kurangnya kerapian dalam penataan buku di perpustakaan sehingga mahasiswa kesulitan mencari buku yang sesuai dengan kebutuhan.

Untuk mengetahui apakah ketidakpuasan mahasiswa Politeknik Negeri Media Kreatif dikarenakan pelayanan pada perpustakaan, maka perlu dilakukan penelitian dengan judul : "Pengaruh Kualitas Pelayanan Perpustakaan terhadap Kepuasan Mahasiswa Di Politeknik Negeri Media Kreatif"

\section{Rumusan Masalah}

Rumusan masalah dalam penelitian ini adalah bagaimana pengaruh kualitas pelayanan perpustakaan terhadap kepuasan mahasiswa di Politeknik Negeri Media Kreatif ?

\section{Tujuan Penelitian}

Tujuan dari penelitian adalah untuk mengetahui pengaruh kualitas pelayanan perpustakaan terhadap kepuasan mahasiswa di Politeknik Negeri Media Kreatif

\section{Kajian Pustaka}

\section{Kualitas Layanan}

Menurut Zeithaml, et.al (2005: 20), Kualitas layanan dapat didefinisikan sebagai seberapa jauh perbedaan antara kenyataan dengan harapan para pelanggan atas layanan yang mereka peroleh. Dengan demikian kualitas layanan merupakan seberapa jauh perbedaan antara kenyataan dan harapan para pelanggan atas layanan yang mereka terima, jika kenyatan lebih jauh dari yang diharapkan maka pelayanan dapat dikatakan sangat baik, sedangkan jika kenyataan kurang dari yang diharapkan maka pelayanan dapat dikatakan tidak baik. Apabila kenyataan sama antara yang diharapkan dengan kenyataan maka layanan disebut baik.

Lebih lanjut Zeithaml, et.al (2005: 28) menyatakan terdapat lima dimensi karakteristik yang digunakan oleh pelanggan dalam mengevaluasi kualitas pelayanan yaitu :

1. Reliability (kepercayaan), yaitu kemampuan suatu perusahaan dalam memberikan pelayanan sesuai yang dijanjikan secara akurat dan terpercaya. Kinerja harus sesuai dengan harapan yang berarti ketepatan waktu, pelayanan yang sama untuk semua pelanggan tanpa kesalahan, sikap simpatik, dan akurasi yang tinggi.

2. Responsiveness (daya tanggap), yaitu suatu kemauan untuk membantu para pelanggan dan memberikan pelayanan dengan tanggap dengan penyampaian informasi yang jelas. Membiarkan konsumen menunggu tanpa adanya suatu alasan yang jelas menyebabkan persepsi yang negatif dalam kualitas pelayanan.

3. Assurance (jaminan), mencakup pengetahuan, kompetensi, kesopan-santunan, respeck terhadap pelanggan, dan sifat dapat dipercaya yang dimiliki para staf yang dapat menumbuhkan rasa percaya perusahaan pada pelanggan.

4. Empathy (empati), yaitu memberikan perhatian yang tulus dan bersifat individual atau pribadi yang diberikan kepada para pelanggan dengan berupaya memahami keinginan pelanggan, di mana perusahaan diharapkan memiliki pengertian dan pengetahuan tentang pelanggan secara penuh, serta memiliki pengoperasian yang nyaman bagi pelanggan.

5. Tangibles (bukti fisik), yaitu kemampuan suatu perusahaan dalam menunjukkan eksistensinya kepada pihak eksternal. Penampilan dan kemampuan sarana dan prasarana fisik perusahaan dan lingkungan sekitarnya adalah bukti nyata dari pelayanan yang diberikan pelanggan.

Menurut Parasuraman (2003: 48) terdapat sepuluh faktor yang menentukan dimensi kualitas yaitu :

1. Realibility (konsistensi kerja), yaitu berupa kemampuan yang dapat dipercaya, perusahaan jasa selalu menepati janji yang pernah diberikan serta memberikan pelayanan pada waktu yang telah ditentukan.

2. Responsiveness (kesiapan merespon), yaitu menyangkut kamauan dan kesiapan perusahaan jasa untuk menyediakan jasa serta menyediakan pelayanan yang cepat. 
3. Competence (pengetahuan dan keterampilan), yaitu menyangkut kemampuan penyampaian jasa ditunjang oleh keahlian dan pengetahuan yang dimiliki untuk mewujudkan suatu pelayanan.

4. Access (kemudahan), yaitu menyangkut kemudahan orang memperoleh jasa, yang dimaksud mengarah kepada kemudahan untuk dihubungi serta waktu pelayanan yang tidak terlalu lama.

5. Courtesy (sikap), yaitu keramahan petugas jasa dalam berhubungan dengan pelanggan.

6. Communication (komunikasi), yaitu memberikan informasi kepada pelanggan dalam bahasa yang mudah dimengerti dan bersedia mendengar keluhan.

7. Credibility (kredibilitas), yaitu kepercayaan terhadap perusahaan pemberi jasa harus dapat dipegang oleh pelanggan dan dituntut kejujuran dari perusahaan terhadap pelanggan atas semua hal yang menyangkut pelayanan.

8. Security (keamanan), yaitu pelanggan harus bebas dari bahaya, resiko, dan kerugian serta rasa gamang atau ragu-ragu.

9. Understand the customer (memahami pelanggan), yaitu membuat kesan positif kepada pelanggan bahwa perusahaan mengerti akan kebutuhannya.

10. Tangibles (bukti fisik), yaitu semua hal-hal yang berhubungan dengan penampilan fisik suatu jasa yang harus sesuai dengan apa yang pernah dijanjikan kepada pelanggan.

Selanjutnya dalam perkembangannya Parasuraman (2003: 247) menjelaskan bahwa dalam sepuluh dimensi yang ada dapat dirangkum menjadi empat dimensi, yaitu :

1. Realibility (konsistensi kerja), yaitu mengukur kemampuan kelambagaan dalam memberikan jasa yang tepat dan dapat diandalkan. Hal ini meliputi fasilitas fisik, perlengkapan, pegawai dan sarana komunikasi serta informasi yang tersedia.

2. Responsiveness (kesiapan merespon), yaitu keinginan para petugas untuk membantu dan memberikan pelayanan sebaik-baiknya kepada pelanggan dengan tanggap.

3. Assurance (jaminan), yaitu mengukur kemampuan dan kesopanan para petugas. Hal ini mencakup pengetahuan, kemampuan, kesopanan, dan sifat dapat dipercaya yang dimiliki para petugas , bebas dari bahaya, resiko, dan keragu-raguan.

4. Emphaty (empati), yaitu mengukur pemahaman petugas terhadap kebutuhan serta perhatian yang diberikan oleh petugas. Hal ini meliputi kemudahan melakukan hubungan, kemudahan tingkat komunikasi, dan nilai pemahaman petugas terhadap kebutuhan pelanggan.

Agar dapat memberikan pelayanan yang sesuai harapan pelanggan perusahaan harus selalu meningkatkan kinerjanya dalam setiap dimensi kualitas di atas dan tidak melakukan overpromise (kelebihan penyampaian) dalam penyampaian informasi kepada pelanggan sehingga menimbulkan harapan yang berbeda dan sulit direalisasikan.

\section{Kepuasan Pelanggan}

Menurut Zeithaml (2005: 78), Kepuasan pelanggan adalah perbandingan antara persepsi pelanggan terhadap jasa yang diterima dan harapannya sebelum menggunakan jasa tersebut. Kepuasan dapat diartikan sebagai upaya pemenuhan sesuatu atau membuat sesuatu memadai, (Tjiptono (2010: 195)). Menurut Oliver (2003: 64) kepuasan adalah tanggapan pelanggan atas terpenuhinya kebutuhan. Sedangkan Kotler (2009: 61) kepuasan adalah perasaan senang atau kecewa seseorang yang dialami setelah membandingkan antara persepsi kinerja atau hasil suatu produk dengan harapan-harapannya.

Menurut Irawan (2009: 39), menjelaskan lima driver utama dalam mengukur kepuasan pelanggan :

1. Driver pertama adalah kualitas produk, pelanggan akan puas kalau setelah membeli dan menggunakan produk tersebut, kalau ternyata kualitas produknya baik. Kualitas produk ini adalah dimensi global yang terdiri dari kinerja, kehandalan, konsistensi dan rancangan produk. 
2. Driver kedua adalah harga, yaitu bagi pelanggan yang sensotif dengan pendapatan yang terbatas biasanya harga murah adalah sumber kepuasan yang penting karena mereka akan mendapatkan value of money yang tinggi. Komponen harga ini relatif tidak penting bagi mereka yang tidak sensitif terhadap harga.

3. Driver ketiga adalah service quality, yaitu sangat bergantung pada tiga hal yaitu sistem, teknologi dan manusia. faktor manusia memegang kontribusi $70 \%$. Pembentukan sikap dan prilaku manusia bukanlah pekerjaan mudah, pembenahan harus dilakukan mulai dari proses rekruitmen, pelatihan, dan budaya kerja yang berkualitas.

4. Driver keempat adalah emotional factor, kepuasan pelanggan dapat timbul pada saat peggunaan produk atau jasa yang memiliki brand image yang baik. Rasa bangga, rasa percaya diri yang timbul dengan menggunakan produk yang berkualitas tertentu, simbol sukses bagian dari kelompok dari orang penting dan sebagainya adalah contoh-contoh emotional value yang mendasari kepuasan pelanggan.

5. Driver kelima adalah berhubungan dengan kemudahan untuk mendapatkan produk atau jasa tersebut. Pelanggan akan semakin puas apabila relatif nyaman dan efisiean dalam mendapatkan produk atau pelayanan yang diberikan oleh perusahaan penghasil produk atau jasa tersebut.

Menurut Zeithaml, et.al (2005: 20), kepuasan pelanggan dapat diukur dengan tiga dimensi yaitu:

1. Produk yang ditawarkan

2. Kualitas pelayanan yang diberikan

3. Perhatian pelayanan

\section{Penelitian Terdahulu}

Penelitian yang dilakukan oleh Yahya dengan judul : Analisis Kualitas Layanan Jasa Pendidikan Terhadap Kepuasan Mahasiswa Pada Politeknik Negeri Sriwijaya dengan populasi berjumlah 4.525 orang dan sampel 96 orang dengan menggunakan alat analisis SPSS (Statistical Product and Service Solution). Kesimpulan yang diperoleh bahwa Politeknik Negeri Sriwijaya perlu mempertimbungkan oleh pihak manajemen yaitu : 1). Manajemen Politeknik Negeri Sriwijaya perlu meningkatkan Faktor assurance dan tangibles kepada mahasiswa agar mahasiswa dapat merasa nyaman dan puas dalam menuntut ilmu di lembaga tersebut, 2). Manajemen Politeknik Negeri Sriwijaya perlu mempertahankan faktor reliability, responsiveness, dan empathy dan bahkan di masa datang untuk lebih ditingkatkan.

Penelitian yang dilakukan oleh Zurni Zahara Samosir (2005) dengan judul: Pengaruh Kualitas Pelayanan Terhadap Kepuasan Mahasiswa Menggunakan Perpustakaan USU (Universitas Sumatera Utara) dengan populasi 26.208 orang dan sampel penelitian 393 orang dengan alat analisis SPSS (Statistical Product and Service Solution). Kesimpulan yang diperoleh bahwa (1) Kualitas pelayanan (kehandalan, daya tanggap, jaminan, empati dan bukti langsung) secara serempak berpengaruh signifikan terhadap kepuasan mahasiswa yang berarti dimensi kualitas pelayanan beserta indikator-indikatornya memberikan pengaruh nyata terhadap kepuasan mahasiswa dalam menggunakan Perpustakaan USU, (2) secara parsial dimensi kehandalan, daya tanggap, empati, dan bukti langsung berpangaruh signifikan terhadap kepuasan mahasiswa, sedangkan dimensi jaminan tidak berpangaruh secara signifikan.

Penelitian yang dilakukan oleh Ferry Yudhy I dan E. Susy Suhendra (2006) dengan judul : Analisis Pengaruh Kualitas Pelayanan Terhadap Kepuasan Nasabah Kredit (Studi kasus BPR Arthaguna Sejahtera). Dengan sampel yang digunakan sebanyak 100 responden, alat analisis SPSS (Statistical Product and Service Solution). Kesimpulan yang dapat diambil adalah : bahwa variabel bebas tangible, reliability, responsiveness, assurance, dan empathy secara individual maupun secara bersama-sama berpangaruh secara signifikan terhadap kepuasan nasabah sebesar 53,2\% variabel tangible, reliability, responsiveness, assurance, dan 
empathy mampu mempengaruhi variabel kepuasan nasabah secara signifikan, sedangkan sebesar 46,7\% dipengaruhi oleh variabel lain yang tidak dimasukkan dalam model.

Penelitian yang dilakukan oleh Tutik Nuranani dan Wiyadi (2012) dengan judul : Pengaruh Kualitas Pelayanan Terhadap Kepuasan Pengguna Jasa Rawat Inap Di RSUD Dr. Moewardi. Dengan populasi sebanyak 29.135 pasien dan sampel yang digunakan sebanyak 70 pasien, alat analisis SPSS (Statistical Product and Service Solution). Kesimpulan yang dapat diambil adalah : bahwa secara simultan dimensi kualitas layanan yang terdiri dari tangibles, reliability, responsiveness, assurance, empathy, competence dan courtesy berpengaruh signifikan terhadap kepuasan pengguna jasa rawat inap, dan secara parsial bahwa dimensi kualitas layanan yang terdiri dari tangibles, assurance, empathy, dan competence berpengaruh positif dan signifikan terhadap kepuasan pengguna jasa rawat inap sedangkan dimensi kualitas layanan terdiri dari reliability, responsiveness, dan courtesy tidak berpengaruh signifikan terhadap kepuasan pengguna jasa rawat inap.

Penelitian yang dilakukan oleh Cokorda Gde Dharma Putra (2011) dengan judul : Analisis Kepuasan Pelanggan Pada Perusahaan Daerah Air Minum (PDAM) Di Kabupaten Jembrana. Dengan populasi sebanyak 110 responden dan sampel yang digunakan sebanyak 52 responden, alat analisis SPSS (Statistical Product and Service Solution). Kesimpulan yang dapat diambil adalah : bahwa semua variabel kualitas layanan berpengaruh signifikan terhadap kepuasan baik secara serentak maupun parsial dan yang paling berpengaruh adalah responsiveness yaitu sebesar 0,708 .

\section{Hipotesis}

Sesuai dengan judul penelitian maka hipotesis penelitian yang adalah Adanya pengaruh kualitas pelayanan perpustakaan terhadap kepuasan mahasiswa di Politeknik Negeri Media Kreatif

\section{Metode Penelitian}

\section{Kerangka Konseptual}

Penelitian dapat dikategorikan sebagai penelitian desriptive reseach karena bertujuan untuk mendeskripsikan suatu fenomena yang terjadi pada dunia nyata. Desain penelitian yang digunakan adalah cross sectional dalam bentuk single cross sectional, dimana pengumpulan data hanya dilakukan dalam satu waktu. Bentuk penelitian adalah kausal untuk menguji hipotesis dan pengaruhnya, serta menjelaskan fungsi dan karakteristik responden dengan menggunakan data primer yang didapat dari kuesioner dan data sekunder yang relevan. Variabel yang diangkat adalah Kualitas Layanan (X) dan variabel Kepuasan Mahasiswa (Y).

Untuk lebih memudahkan pemahaman tentang kerangka pemikiran penelitian ini, maka dilihat dalam sistematis kerangka pemikiran sebagai berikut :

Kerangka pemikiran penelitian sebagai pedoman analisis lebih lanjut, yaitu :

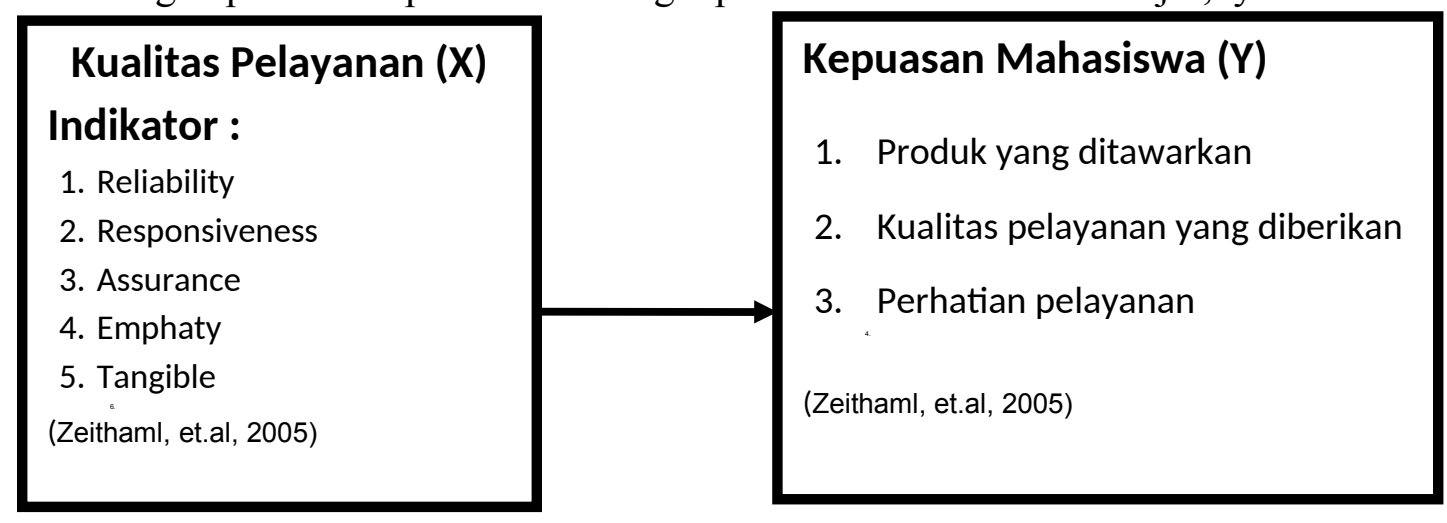

Gambar 1 Kerangka Pemikiran 


\section{Lokasi dan Waktu Penelitian}

Penelitian ini dilaksanakan pada Politeknik Negeri Media Kreatif, yang beralamat Jl. Srengseng Sawah, Jagakarsa, Jakarta 12640. Dengan waktu penelitian selama 3 (enam) bulan. Jenis Data Penelitian

Menurut Sekaran (2009: 77), Jenis data yang digunakan dalam penelitian terdiri dari :

a. Data Primer

Data primer adalah data yang dikumpulkan untuk penelitian dari tempat aktual terjadinya peristiwa. Dalam penelitian ini data primer berupa hasil wawancara penulis dengan mahasiswa Politeknik Negeri Media Kreatif.

b. Data Sekunder

Data sekunder merupakan data yang telah ada dan tidak perlu dikumpulkan sendiri oleh peneliti. Dalam hal ini data sekunder yang diperoleh penulis berupa keadaan umum Perpustakaan Politeknik Negeri Media Kreatif.

Penelitian ini membutuhkan data primer yang lebih banyak dibandingkan dengan data sekunder. Data primer dikumpulkan melalui wawancara dengan bantuan kuesioner yang tersedia. Data sekunder diperoleh dari berbagai referensi yang terkait dengan penelitian baik laporan, jurnal atau beberapa referensi penelitian yang terdahulu yang relevansi kajian yang dilakukan.

Perolehan data lainnya dilakukan melalui pengamatan langsung dan pengamatan terlibat memberikan banyak kemungkinan bagi peneliti untuk menemukan fenomena yang sebenarnya. Hal ini pada gilirannya dapat memberikan gambaran tentang objek penelitian secara lebih mendalam.

\section{Teknik Penentuan Sampel}

Responden penelitian tersebar di tiga jurusan yang berbeda, maka dalam penelitian ini penentuan sampel yang digunakan adalah teknik sampel acak (random sampling).

\section{Teknik Pengumpulan Data}

Dalam penelitian ini, teknik yang digunakan Penulis untuk memperoleh dan mengumpulkan data penelitian yang diperlukan, Menurut Sugiyono (2007: 130-138) adalah :

a. Studi Lapangan

1) Wawancara

Yaitu metode pengumpulan data yang dilakukan dengan cara bertanya langsung dengan pihak-pihak yang dianggap membantu dalam mendapatkan data yang diperlukan.

2) Dokumentasi

Yaitu metode pengumpulan data yang dilakukan dengan cara mengutip catatancatatan, laporan keuangan dan laporan Rapat Anggota Tahunan (RAT) yang kemudian diolah menjadi data penunjang dalam pembahasan.

3) Observasi

Yaitu metode pengumpulan data yang melalui pengamatan dan pencatatan oleh pengumpul data terhadap gejala / peristiwa yang diselidiki pada obyek penulis.

b. Studi Kepustakaan

Yaitu metode pengumpulan data dengan cara mempelajari literatur yang berhubungan dengan objek yang diteliti melalui teori yang dipelajari pada mata kuliah Sistem Informasi Manajemen, buku-buku, pedoman, dan literatur yang berhubungan dengan masalah penelitian. 
Tabel 2

Operasional Variabel Penelitian

\begin{tabular}{|c|c|c|c|c|}
\hline Variabel & Definisi & Indikator & Skala & Item \\
\hline \multirow{5}{*}{$\begin{array}{c}\text { Kualitas } \\
\text { Pelayanan }(X)\end{array}$} & \multirow{3}{*}{$\begin{array}{lr}\text { Seberapa } & \text { jauh } \\
\text { perbedaan } & \text { antara } \\
\text { kenyataan } & \text { dengan } \\
\text { harapan } & \text { para } \\
\text { pelanggan } & \text { atas } \\
\text { layanan } & \text { yang } \\
\text { mereka peroleh }\end{array}$} & $\begin{array}{l}\text { Reliability } \\
\text { 1. Ketepatan waktu bila berjanji } \\
\text { 2. Jujur dalam pelayanan } \\
\text { 3. Kesiapan petugas melayani pelanggan } \\
\text { setiap waktu }\end{array}$ & Likert & $1-3$ \\
\hline & & $\begin{array}{l}\text { Responsiveness } \\
\text { 1. Kesediaan membantu konsumen } \\
\text { 2. Komunikasi yang baik } \\
\text { 3. Kecepatan pelayanan } \\
\end{array}$ & Likert & $4-6$ \\
\hline & & $\begin{array}{l}\text { Assurance } \\
\text { 1. Karamahan karyawan } \\
\text { 2. Petugas memberikan informasi yang } \\
\text { jelas dalam pelayanan } \\
\text { 3. Pengetahuan karyawan yang memadai }\end{array}$ & Likert & $7-9$ \\
\hline & $\begin{array}{l}\text { Zeithaml, et.al } \\
(2005: 20),\end{array}$ & $\begin{array}{l}\text { Emphaty } \\
\text { 1. Kesediaan karyawan dalam menerima } \\
\text { keluhan dan pengaduan } \\
\text { 2. Tanggung jawab keamanan dan } \\
\text { kenyaman } \\
\text { 3. Perhatian terhadap kebutuhan } \\
\text { konsumen }\end{array}$ & Likert & $10-12$ \\
\hline & & $\begin{array}{l}\text { Tangible } \\
\text { 1. Kebersihan ruangan } \\
\text { 2. Kerapian karyawan } / \text { staff } \\
\text { 3. Penataan tempat }\end{array}$ & Likert & $13-15$ \\
\hline $\begin{array}{l}\text { Kepuasan } \\
\text { mahasiswa } \\
\quad(Y)\end{array}$ & $\begin{array}{l}\text { Perasaan senang / } \\
\text { kecewa seseorang } \\
\text { yang berasal dari } \\
\text { perbandingan } \\
\text { antara kesannya } \\
\text { terhadap kinerja } \\
\text { serta } \\
\text { harapan } \\
\\
\text { Kotler }(2009: 61)\end{array}$ & $\begin{array}{l}\text { 1. Produk yang ditawarkan dapat } \\
\text { memenuhi kebutuhan konsumen } \\
\text { 2. Kesusaian kualitas pelayanan dengan } \\
\text { tingkat harapan konsumen } \\
\text { 3. Perasaan puas atas perhatian dan } \\
\text { pelayanan yang diberikan }\end{array}$ & $\begin{array}{l}\text { Ordin } \\
\text { al }\end{array}$ & $1-3$ \\
\hline
\end{tabular}

\section{Teknik Analisis Data}

Pengujian Validitas Data

Menurut Sugiyono (2007: 172), pengujian validitas tiap butir digunakan analisis item, yaitu dengan mengkorelasikan skor tiap butir dengan skor total. Kevalidan itu perlu sebab prosesing data yang tidak sahih/valid atau bias akan menghasilkan kesimpulan bukan dari objek. Suatu instrumen dapat dinyatakan valid, jika instrumen tersebut mampu mengukur apa yang hendak diungkapkannya dalam penelitian. Uji validitas ini dapat dilakukan terhadap nilai setiap variabel dengan teknik korelasi skor item atau butir penyataan dengan skor total 
item, dengan menggunakan koefisien korelasi Product Momen Pearson (r). Item yang akan dimasukkan dalam analisis akhir adalah item yang memiliki nilai $r$ lebih dari nilai kritis atau nilai tabel dengan taraf nyata $\mathrm{a}=0.05(5 \%)$.

- Jika nilai Sig (2-tailed) < dari nilai $\alpha=5 \%$ maka pernyataan valid $\&$ bisa digunakan dalam penelitian.

- Jika nilai Sig (2-tailed) $>$ dari nilai $\alpha=5 \%$ maka pernyataan tidak valid $\&$ tidak bisa digunakan dalam penelitian selanjutnya.

\section{Pengujian Reliabilitas Data}

Uji reliabilitas dimaksud untuk mengetahui adanya konsistensi alat ukur dalam penggunaannya. Menurut Sugiyono (2007: 191), menyatakan reliabilitas kurang dari 0,6 dianggap buruk, kehandalan dalam kisaran 0,7 bisa diterima dan lebih dari 0.8 adalah baik. Kehandalan yang menyangkut kekonsistenan jawaban jika diujikan berulang pada sampel yang berbeda. SPSS memberikan fasilitas untuk mengukur reliabilitas dengan uji statistik Cronbach Alpha (a). Suatu konstruk dikatakan reliabel jika memberikan nilai Alpha Cronbach $>0,60$. Dalam penelitian ini teknik yang digunakan untuk mengetahui reliabilitas instrumen adalah rumus Alpha Cronbach Arikunto (2010: 96)

$$
\mathrm{r} 11\left[\frac{K}{K-1}\right]\left[1-\frac{\sum \sigma \frac{2}{b}}{\sigma \frac{2}{t}}\right]
$$

Keterangan :

$\mathrm{r} 11=$ Reliabilitas instrumen

$\mathrm{K}=$ Banyaknya butir pertanyaan atau banyaknya soal

$\sum \sigma \frac{2}{b}=$ Jumlah varians butir

$\sigma \frac{2}{t}=$ Varians total

\section{Analisis Regresi Sederhana}

Model analisis ini digunakan untuk melihat pengaruh beberapa variabel bebas terhadap variabel terikat dengan model dasar sebagai berikut :

$$
\begin{array}{ll}
\mathrm{Y}=\alpha+B X+\mathrm{e} & \\
\text { Keterangan : } & \\
\mathrm{Y} & =\text { Kepuasan mahasiswa } \\
\mathrm{a} & =\text { konstanta } \\
\beta \mathrm{i} & =\text { koefisien variabel bebas } \\
\mathrm{X} & =\text { Kualitas Layanan } \\
\mathrm{e} & =\text { Error term }
\end{array}
$$

Nilai koefisien regresi di sini sangat menentukan dalam proses analisis, mengingat penelitian ini bersifat fundamental method. Hal ini berarti jika koefisien b bernilai positif $(+)$ maka dikatakan terjadi pengaruh searah antara variabel bebas dengan variabel terikat, setiap kenaikan variabel bebas akan mengakibatkan kenaikan variabel terikat. Demikian pula sebaliknya, bila koefisien b bernilai negatif (-), hal ini menunjukkan adanya pengaruh negatif dimana kenaikan nilai variabel bebas mengakibatkan penurunan nilai variabel terikat.

\section{Analisis Korelasi}

Analisis korelasi digunakan tujuan untuk mengetahui ada tidaknya hubungan (korelasi) antara variabel, untuk melihat besar kecilnya hubungan antar variabel, dan untuk memperoleh kejelasan dan kepastian apakah hubungan tersebut signifikan atau tidaknya signifikan. Untuk mencari hubungan fungsional tersebut digunakan. 


$$
\mathbf{r}_{\mathbf{x y}}=\frac{n \sum x y-\sum x \sum y}{\sqrt{n \sum_{x} 2-i \dot{i} \dot{i}}}
$$

Keterangan :

\begin{tabular}{|c|c|}
\hline Rxy & $=$ koefisien korelasi \\
\hline $\mathrm{N}$ & $=$ jumlah subyek / responden \\
\hline $\mathrm{X}$ & $=$ nilai skor butir $/$ nilai skor tertentu \\
\hline Y & $=$ nilai skor total \\
\hline$\sum x^{2}$ & $=$ jumlah kuadrat nilai $\mathrm{X}$ \\
\hline$\sum y^{2}$ & $=$ jumlah kuadrat nilai $\mathrm{Y}$ \\
\hline
\end{tabular}

\section{Uji Hipotesis (Uji t)}

Menurut Sugiyono (2007: 221), suatu hipotesis dibuktikan melalui data-data yang terkumpul, secara statistik hipotesis diartikan sebagai pertanyaan mengenai keadaan populasi yang akan diuji kebenarannya berdasarkan data yang diperoleh dari sampel penelitian, Hipotesis dalam penelitian ini adalah:

Ho : Variabel kualitas pelayanan tidak berpengaruh terhadap Kepuasan mahasiswa Politeknik Negeri Media Kreatif

Ha : Variabel kualitas pelayanan berpengaruh terhadap Kepuasan mahasiswa Politeknik Negeri Media Kreatif

Kriteria penilaian :

H0 diterima : sig $\mathrm{t}>0,05$ atau $\mathrm{t}$ hitung $\leq \mathrm{t}$ tabel

H0 ditolak $\quad:$ sig $\mathrm{t}<0,05$ atau $\mathrm{t}$ hitung $>\mathrm{t}$ tabel

\section{Hasil Dan Pembahasan}

\section{Hasil}

Deskripsi responden

Tabel 3. Deskripsi Responden

\begin{tabular}{|l|c|r|}
\hline \multicolumn{1}{|c|}{ Jenis Kelamin } & Jumlah Responden & Prosentase (\%) \\
\hline Laki-laki & 103 & 48,82 \\
\hline Perempuan & 108 & 51,18 \\
\hline Jumlah & 211 & 100 \\
\hline
\end{tabular}

Sumber: Politeknik Negeri Media Kreatif2018

Dari data di atas dapat dijelaskan bahwa sebagian besar responden berjenis kelamin laki-laki yakni 48,82\% atau 103 responden dan sebanyak 108 orang atau 51,18\% berjenis kelamin perempuan.

\section{Hasil Uji Intrumen Data}

\section{Uji Validitas Variabel Kepuasan Mahasiswa dan Kualitas Layanan}

Item pertanyaan variabel kepuasan mahasiswa terdiri dari 3 pertanyaan, berdasarkan hasil pengolahan data primer dengan program SPSS, uji validitas instrumen penelitian untuk variabel kepuasan mahasiswa dengan 3 item pertanyaan adalah sebagai berikut :

Tabel 4 Hasil olah Validitas Variabel Kepuasan Mahasiswa

\begin{tabular}{|l|c|c|c|c|}
\hline No. & Item & $\begin{array}{c}\text { Corrected Item- } \\
\text { Total Correlation }\end{array}$ & $\begin{array}{c}\mathbf{r}_{\text {tabel }} \\
(\boldsymbol{\alpha}=\mathbf{5 \%})\end{array}$ & $\begin{array}{c}\text { Hasil Uji } \\
\text { Validitas }\end{array}$ \\
\hline 1. & Y_1 & 0,743 & 0,1351 & Valid \\
\hline 2. & Y_2 & 0,658 & 0,1351 & Valid \\
\hline 3. & Y_3 & 0,667 & 0,1351 & Valid \\
\hline
\end{tabular}


Sumber : Hasil olah program SPSS (lampiran)

Dari hasil pengolahan data menggunakan bantuan program SPSS menunjukkan hasil uji validitas dari 3 item pertanyaaan/pernyataan variabel Kepuasan mahasiswa (Y) tersebut valid pada taraf nyata $(\alpha)=5 \%$ yang berarti semua item pertanyaan/pernyataan yang ada pada instrumen tersebut dapat dijadikan sebagai alat ukur yang valid dalam analisis selanjutnya.

Berdasarkan hasil pengolahan data primer dengan SPSS, uji validitas instrumen penelitian untuk variabel kualitas layanan dengan 15 item pertanyaan adalah :

Tabel 5 Hasil olah Validitas Variabel Kualitas Layanan

\begin{tabular}{|l|c|c|c|c|}
\hline No. & Item & $\begin{array}{c}\text { Corrected Item- } \\
\text { Total Correlation }\end{array}$ & $\begin{array}{c}\mathbf{r}_{\text {tabel }} \\
(\boldsymbol{\alpha}=\mathbf{5 \%} \boldsymbol{)})\end{array}$ & $\begin{array}{c}\text { Hasil Uji } \\
\text { Validitas }\end{array}$ \\
\hline 1. & X_1 & 0,377 & 0,1351 & Valid \\
\hline 2. & X_2 & 0,322 & 0,1351 & Valid \\
\hline 3. & X_3 & 0,243 & 0,1351 & Valid \\
\hline 4. & X_4 & 0,317 & 0,1351 & Valid \\
\hline 5. & X_5 & 0,325 & 0,1351 & Valid \\
\hline 6. & X_6 & 0,344 & 0,1351 & Valid \\
\hline 7. & X_7 & 0,304 & 0,1351 & Valid \\
\hline 8. & X_8 & 0,305 & 0,1351 & Valid \\
\hline 9. & X_9 & 0,329 & 0,1351 & Valid \\
\hline 10. & X_10 & 0,366 & 0,1351 & Valid \\
\hline 11. & X_11 & 0,400 & 0,1351 & Valid \\
\hline 12. & X_12 & 0,337 & 0,1351 & Valid \\
\hline 13. & X_13 & 0,179 & 0,1351 & Valid \\
\hline 14. & X_14 & 0,242 & 0,1351 & Valid \\
\hline 15. & X_15 & 0,203 & 0,1351 & Valid \\
\hline
\end{tabular}

Sumber : Hasil olah program SPSS

Dari hasil pengolahan data menggunakan bantuan program SPSS menunjukkan hasil uji validitas dari 15 item pertanyaaan/pernyataan variabel kualitas layanan tersebut valid pada taraf nyata $(\alpha)=5 \%$ yang berarti semua item pertanyaan/pernyataan yang ada pada instrumen tersebut dapat dijadikan sebagai alat ukur yang valid dalam analisis selanjutnya.

\section{Uji Reliabilitas Data}

Reliabilitas merujuk pada pengertian bahwa suatu instrumen dapat dipercaya untuk digunakan sebagai alat ukur. Pengujian reliabilitas instrumen dalam penelitian ini menggunakan batasan nilai kritis product moment $(\alpha)$ sebesar 0,6 .

Tabel 6 Hasil Uji Reliabilitas

\begin{tabular}{|c|l|c|c|c|}
\hline $\begin{array}{c}\text { No } \\
\cdot\end{array}$ & \multicolumn{1}{|c|}{ Variabel } & $\begin{array}{c}\text { Cronbach's } \\
\text { Alpha Item }\end{array}$ & $\begin{array}{c}\text { Nilai } \\
\text { Alpha }\end{array}$ & $\begin{array}{c}\text { Hasil Uji } \\
\text { Reliabilita } \\
\text { s }\end{array}$ \\
\hline 1. & Kepuasan Mahasiswa & 0,745 & 0,600 & Reliabel \\
\hline 2. & Kualitas Layanan & 0,632 & 0,600 & Reliabel \\
\hline
\end{tabular}

Sumber : Hasil Pengolahan Data dengan SPSS

Dari hasil pengolahan data menggunakan bantuan program SPSS for Windows menunjukkan bahwa semua variabel yang akan digunakan dalam penelitian ini mempunyai nilai cronbach's alpha di atas 0,6. Dari hasil tersebut menunjukkan bahwa semua indikator tersebut dapat dijadikan sebagai alat ukur yang reliabel dalam analisis selanjutnya.

\section{Analisis Regresi Linier Sederhana}

Analisis regresi sederhana digunakan untuk melihat besaran pengaruh kuliatas layanan $(\mathrm{X})$ terhadap kepuasan mahaiswa $(\mathrm{Y})$. Hasil pengolahan data dengan menggunakan SPSS ditampilkan dalam tabel sebagai berikut : 
Tabel. 7 Hasil Uji Regresi Linier Sederhana

Coefficients $^{\mathbf{a}}$

\begin{tabular}{|c|c|c|c|c|c|c|}
\hline \multirow{2}{*}{\multicolumn{2}{|c|}{ Model }} & \multicolumn{2}{|c|}{$\begin{array}{c}\text { Unstandardized } \\
\text { Coefficients }\end{array}$} & $\begin{array}{l}\text { Standardized } \\
\text { Coefficients }\end{array}$ & \multirow[t]{2}{*}{$\mathrm{t}$} & \multirow[t]{2}{*}{ Sig. } \\
\hline & & $\mathrm{B}$ & $\begin{array}{l}\text { Std. } \\
\text { Error }\end{array}$ & Beta & & \\
\hline \multirow{2}{*}{1} & (Constant) & 13,965 & 1,817 & & 7,685 &, 000 \\
\hline & Kualitas layanan &, 037 &, 032 &, 080 & 2,155 & ,024 \\
\hline
\end{tabular}

a. Dependent Variable: kepuasan mahasiswa

Dari hasil analisis regresi dengan menggunakan bantuan program SPSS dapat dibuat persamaan regresi bergandanya sebagai berikut :

$$
\begin{aligned}
& Y=\alpha+B x+e \\
& Y=13,965+0,037 X
\end{aligned}
$$

Dari persamaan regresi dapat digambarkan bahwa :

1) Konstanta sebesar 13,965 berarti jika tidak ada peningkatan dalam kualitas layanan maka Kepuasan mahasiswa adalah sebesar 13,965 satuan skor

2) Nilai koefisien kualitas layanan sebesar 0,037 berarti bahwa jika variabel kualitas layanan meningkat sebesar 1 satuan skor maka variabel kepuasan mahasiswa juga meningkat sebesar 0,037 satuan skor.

\section{Analisis Korelasi}

Analisis korelasi (r) digunakan untuk mengukur tinggi rendahnya derajat hubungan antara variabel yang diteliti. Tinggi rendahnya derajat keeratan tersebut dapat dilihat dari koefisien korelasinya. Adapun untuk hasil perhitungan korelasi dalam bab ini dapat dilihat dari tabel 4.8 dibawah ini :

\section{Tabel 8 Hasil Uji Korelasi}

\section{Correlations}

\begin{tabular}{|ll|r|r|}
\hline & & \multicolumn{1}{|c|}{$\begin{array}{c}\text { Kualitas } \\
\text { Layanan }\end{array}$} & $\begin{array}{c}\text { Kepuasan } \\
\text { Mahasiswa }\end{array}$ \\
\hline \multirow{3}{*}{ Kualitas Layanan } & Pearson Correlation & 1 &, 080 \\
& Sig. (2-tailed) & &, 249 \\
& $\mathrm{~N}$ & 211 & 211 \\
& Pearson Correlation &, 080 & 1 \\
Kepuasan Mahasiswa & Sig. (2-tailed) &, 249 & 211 \\
& $\mathrm{~N}$ & 211 & \\
\hline
\end{tabular}

Berdasarkan tabel 8 maka didapatkan nilai pearson correlation sebesar 0,08 . Dari penafsiran terhadap koefisien korelasi tersebut dapat diketahui bahwa nilai pearson correlation berada di rentan 0,000-0199, itu berarti terjadi hubungan positif yang rendah antara kualitas layanan perpustakaan dan kepuasan mahasiswa

\section{Uji Hipotesis}

Uji t digunakan untuk mengetahui apakah variabel bebas berpengaruh signifikan terhadap variabel terikat atau untuk mengetahui apakah model regresi dapat digunakan untuk memprediksi variabel terikat atau tidak. 
Dari tabel 7 dapat dilihat bahwa t hitung untuk variabel kualitas layanan terhadap Kepuasan mahasiswa (Y) adalah sebesar 2,155, hal ini berarti $t_{\text {hitung }}>t_{\text {tabel }}(2,155>1,971)$, oleh karena $t_{\text {hitung }}>t_{\text {tabel }}$ maka $\mathrm{H} 1$ diterima dan $\mathrm{H} 0$ ditolak, artinya secara parsial ada pengaruh secara siginifikan antara variabel kualitas layanan perpustakaan terhadap Kepuasan mahasiswa di Politeknik Negeri Media Kreatif

\section{Pembahasan}

Penulis akan menjabarkan tentang hasil penelitian pengaruh kualitas pelayanan perpustakaan terhadap kepuasan mahasiswa di Politeknik Negeri Media Kreatif, dengan responden berjumlah 211 responden. Hasil temuan di lapangan bagi pihak-pihak yang terkait adalah simpulan yang diperoleh variabel kualitas pelayanan perpustakaan berpengaruh signifikan terhadap kepuasan mahasiswa di Politeknik Negeri Media Kreatif, jika di bandingkan dengan penelitian terdahulu yang dilakukan Yahya, Zurni Zahara Samosir, Ferry Yudhy I dan E. Susy Suhendra, penelitian Tutik Nuranani dan Wiyadi, serta Cokorda Gde Dharma Putra yang hasilnya memiliki kesamaan yaitu variabel kualitas pelayanan berpengaruh signifikan terhadap variabel kepuasan walaupun dilakukan di tempat yang berbeda dan dalam waktu yang berbeda juga.

\section{Kesimpulan}

Setelah mempelajari data yang diperoleh dari responden dan pembahasan yang dilakukan, maka simpulan hasil penelitian adalah variabel kualitas layanan perpustakaan (X) berpengaruh secara signifikan terhadap variabel terikat kepuasan mahasiswa Politeknik Negeri Media Kreatif.

1. Hasil analisis regresi linier sederhana, nilai koefisien kualitas layanan perpustakaan sebesar 0,037 berarti bahwa jika variabel kualitas layanan perpustakaan meningkat sebesar 1 satuan skor maka variabel kepuasan mahasiswa juga meningkat sebesar 0,037 satuan skor dan memiliki pengaruh yang positif atau searah.

2 .

Hasil uji korelasi, nilai pearson correlation sebesar 0,080 , dengan begitu nilai pearson correlation berada pada interval 0,000- 0,199, itu berarti terjadi hubungan positif yang rendah antara kualitas layanan perpustakaan dan kepuasan mahasiswa.

\section{Daftar Pustaka}

Alma, Buchari. 2012. Manajemen pemasaran dan Manajemen Jasa. Bandung: Salemba Empat.

Arikunto, Suharsimi. 2010. Prosedur Penelitian: Suatu Pendekatan Praktik. Jakarta : Rineka Cipta.

Assauri, Sofyan. 2011, Manajemen Pemasaran, PT. Raja Grafindo Persada, Jakarta.

Bangun, Burhan. 2012. Dasar-Dasar manajemen. Jakarta : Kencana.

Banks, Jerry. 2006. Principle of Quality Control, New York : John Wiley and Sons.

Boyd, Walker. 2008. Manajemen Pemasaran Jakarta : Erlangga.

Cokorda Gde Dharma Putra. 2011. "Analisis Kepuasan Pelanggan Pada Perusahaan Daerah Air Minum (PDAM) di Kabupaten Jembrana".

Drummond Ellen, J. 2005. "Learning From the Quality Improvement Process : Experience from US Manufacturing Firms", Production and Inventory Management Journal, Forth Quarter, pp 7 - 13.

Griffin, Ricky W. 2010. Manajemen. Jakarta : Erlangga.

Hasibuan, Melayu. 2010. Manajemen Sumber Daya Manusia. Jakarta : Bumi Aksara.

Ferry Yudhy I dan DR. E Susy Suhendra. 2006. "Analisis Pengaruh Kualitas Layanan Terhadap Kepuasan Nasabah Kredit (Studi Kasus BPR Arthaguna Sejahtera).

Irawan, Handi D. 2009. Prinsip Kepuasan Pelanggan, Jakarta, PT. Elex Media Komputindo. 
Kotler, Philip. 2009. Marketing Manajement : Analysis, Planning, Implementation, and Control, New Jersey : Prentice Hall International, Inc.

Kotler, Philip dan Gary Armstrong. 2012. Prinsip-prinsip Pemasaran. Jakarta: Penerbit Erlangga

Kotler, Philip dan Kevin Lane Keller. 2009. Manajemen Pemasaran. Jakarta: Salemba Empat

Lupiyoadi, Rambat dan A. Hamdani. 2009. Manajemen Pemasaran Jasa. Jakarta: Indeks

Oliver. 2003. Great Answer to Tough the Marketing Question, PT. Prenhalindo. Jakarta.

Parasuraman. 2003. Marketing Research. New York: Addison Wesley Publishing Co.

Rangkuti, Freddy, 2009. Manajemen Pemasaran, Jakarta: Gramedia Pustaka Utama

Reeves, Carol A. And David Bednar. 2004. “Defining Quality : Quality Alternatives and Implications”, The Academy of Management Review, Vol 19(3), July, PP 419 - 429 Penerbit Salemba Empat, Jakarta.

Richard, Daft.L, 2013. Era Baru Manajemen, Terjemahan Tita Maria Kanita. Jakarta: Salemba Empat.

Ricky, W. 2015. Manajemen,. Jakarta: Erlangga.

Robbin, Stephen, P. Dan Coulter, Mary, 2012. Manajemen, Jakarta: PT. Indel- -

Sabran. 2010. Manajemen Pemasaran. Bandung. CV Yrama Widya

Setiyaningrum, Ari, 2015. Prinsip-Prinsip Pemasaran. Yogyakarta : ANDI

Siswanto, Sastrohadiwiryo. 2011, Manajemen Tenaga Kerja Indonesia, Jakarta : P ı. Dumı Aksara

Sekaran, Uma. 2009. Metodologi Penelitian Untuk Bisnis”, Edisi 4. Buku 2. Jakarta: Salemba Empat.

Sugiyono. 2007. Metode Penelitian Administrasi, Bandung : Alfabeta.

Tutik Nuranani, Wiyadi. 2012. "Pengaruh Kualitas Pelayanan Terhadap Kepuasan Pengguna Jasa Rawat Inap Di RSUD Dr.Moewardi".

Yahya. 2013." Analisis Kualitas Layanan Jasa Pendidikan Terhadap Kepuasan Mahasiswa Pada Politeknik Negeri Sriwijaya". ( Tesis master yang tidak dipublikasikan) Universitas Muhammadiyah Palembang, Palembang, Indonesia

Yusi, M. Shahirman dan Umiyati Idris. 2009. Metodologi Penelitian Ilmu Sosial : Pendekatan Kuantitaif. Palembang : Penerbit Citrabooks Indonesia.

Zeithaml, Valerie, et.al. 2005. Delivering Quality Service: Balancing Customer Perception and Expectation, New York: The McGraw-Hill Company, Inc

Zurni Zahara Samosir. 2005, “ Pengaruh Kualitas Pelayanan Terhadap Kepuasan Mahasiswa Menggunakan Perpustakaan USU (Universitas Sumatera Utara)” 